\title{
Problems of determining the mental element in crime under article 264 of the Criminal Code of the Russian Federation
}

\author{
Alla Vasilyevna Vashkevich ${ }^{1}$, Aleksander Vladimirovich Nikishkin $^{2}$, Boris Vasilyevich \\ Epifanov $^{3 *}$, Ramin Anatolievich Ramazanov ${ }^{3}$, and Victoria Anatolievna Smorodina ${ }^{4}$ \\ ${ }^{1}$ Saint Petersburg University of the Ministry of Internal Affairs of Russia, Department of Legal \\ Psychology, Saint Petersburg, Russia \\ ${ }^{2}$ Saint Petersburg University of the Ministry of Internal Affairs of Russia, Department of Special \\ Events and Special Equipment, Saint Petersburg, Russia \\ ${ }^{3}$ Saint Petersburg University of the Ministry of Internal Affairs of Russia, Department of Criminal \\ Law, Saint Petersburg, Russia \\ ${ }^{4}$ Saint Petersburg University of the Ministry of Internal Affairs of Russia, Department of Personnel \\ Management and Educational Work, Saint Petersburg, Russia
}

\begin{abstract}
It should be mentioned that any particular traffic accident is most often a concurrence of a number of causes and factors associated with any of the subsystems "Driver - Car - Road - Environment". As evidenced by judicial practice, crimes under Article 264 of the Criminal Code of the Russian Federation are traditionally qualified by courts as committed in a careless form of guilt in the form of criminal flippancy. However, there may exist doubts about the correct assessment of the mental element in these crimes. The main question is if these crimes were intentional. The relevance of the study is conditional upon the need to develop a system of prevention of road traffic injuries and improve the effectiveness of measures to prevent them. The purpose of the study is to analyze theoretical problems and the results of empirical observation for road safety. This article is devoted to the relevant problem of accurate determination of the form of guilt in violation by the person driving the vehicle of road traffic regulations on the example of the analysis of the crime under Article 264 of the Criminal Code of the Russian Federation "Violation of road traffic regulations and the rules of operation of vehicles." In the preparation of the article, general scientific methods (dialectical, logical, socio-scientific method, method of system analysis) and interdisciplinary methods (sociological, statistical, method of the research of specific facts) were used. The novelty of the study is in an attempt to deeply analyze and interpret the practical application of the provisions of Article 264 of the Criminal Code of the Russian Federation, identify the problem of accurate determination of the form of the guilt of the mentioned act committed by the person driving the vehicle when violating road traffic regulations or the rules operation of vehicles.
\end{abstract}

Keywords: traffic accident, road safety, criminal sanctions, justice

\footnotetext{
* Corresponding author: epifanov-mvd@mail.ru
} 


\section{Introduction}

As of today, the problem of criminal violation of road traffic regulations (hereinafter referred to as RTR) has become particularly relevant. Dangerous driving is studied not only by lawyers, but also by psychologists in specific situations and involves deep study of internal clinical, psychophysiological, cognitive, motivational, and semantic aspects, as well as the psychological characteristics of persons inclined to alcohol and drug addiction [1]. In the process of driving a vehicle, in such situations, not only the nature and degree of public danger of the act changes but also the form of guilt, that is, crimes against the person and public order are committed.

Judicial practice indicates that within the same legal family, the criminal-legal assessment of the behavior of the perpetrators in Russia and, for example, in Germany significantly differs. For example, the Land Court of Berlin sentenced two "street racers" to life imprisonment. These drivers, aged 25 and 28, initiated illegal races in Berlin on the night of February 1, 2016. One of the drivers crashed into a Jeep. The SUV overturned and the 69year-old driver was killed in the accident. It took the court a year to give an accurate legal assessment of this crime. The prosecutor's office qualified it as murder, arguing that the organizers of the street race, although they did not intend to kill anyone, still did not exclude the possibility of fatal consequences.

A completely different legal assessment of such an act has been given in Russia.

On September 21, 2020, in Moscow, rapper Guliyev, while driving an Infiniti car, committed a resonant accident - hitting a pedestrian with causing serious harm to health and death. Previously Guliyev was brought to administrative responsibility for traffic violations 49 times. He was charged with committing a crime under paragraph "a" of Part 1 of Article 264 of the Criminal Code of the Russian Federation - a violation of the road traffic regulations and rules of operation of vehicles, resulting in negligent infliction of serious harm to human health" [2]. Drugs were found in the rapper's blood. This gives reason to believe that this crime was committed by Guliyev, most likely, intentionally. However, in this case, he might be prosecuted under Article 264 of the Criminal Code of the Russian Federation, which raises doubts about the correct assessment of what has been done.

\section{$2 \quad$ Methods}

The article uses general scientific methods, such as dialectical method, logical method, and the method of system analysis.

The search for foreign research materials was performed in the science direct search engine (www.sciencedirect.com). The search mode "search all fields, journal or book title" was used (search in all areas, in the title of the magazine or book); search words: road safety, traffic psychology. The search for materials of domestic research was performed in the research gate search engine (https://www.researchgate.net/), eLIBRARY.RU (https://elibrary.ru/defaultx.asp). As a result of the search, some conference materials, a statistical collection, and articles were selected. The summary data is presented in the table.

\section{$3 \quad$ Results}

Among the many problems that cause interpretation and application in practice of article 264 of the Criminal Code of the Russian Federation, a special place is occupied by the problem of accurate establishing of the mental state of this crime, the content and form of guilt when a person driving a vehicle violates road traffic regulations and rules of its operation on the example of the analysis of the crime provided by this article. 
Table 1. Analysis of the problem.

\begin{tabular}{|l|l|l|}
\hline No. & \multicolumn{1}{|c|}{ Author } & \multicolumn{1}{|c|}{ Results } \\
\hline 1. & Rarog [3] & $\begin{array}{l}\text { According to Rarog, a person's awareness of the public danger of } \\
\text { the committed act is not a mandatory feature of frivolity, since it } \\
\text { does not directly follow from the law. }\end{array}$ \\
\hline 2. & Filanovsky [16] & $\begin{array}{l}\text { Filanovsky believes that in the absence of awareness of the public } \\
\text { danger of his/her act when committing crimes in the form of } \\
\text { arrogance (frivolity). }\end{array}$ \\
\hline 3. & Dagel [5] & $\begin{array}{l}\text { Dagel noted the peculiarities of committing careless crimes in the } \\
\text { sphere of operation of technical means or other sources of } \\
\text { increased danger. These actions result in } \\
\text { the loss of control of technical means managing them, which leads } \\
\text { to dangerous consequences }\end{array}$ \\
\hline 4. & Korobeev [6] & $\begin{array}{l}\text { According to Korobeev, mixed form of guilt is therefore called so } \\
\text { because it is characterized by the heterogeneity of the mental } \\
\text { attitude to the act and its consequences. }\end{array}$ \\
\hline 5. & Ivanov [7] & $\begin{array}{l}\text { According to Ivanov, in order to establish guilt, the mandatory } \\
\text { knowledge of the rules of the Criminal Code of the Russian } \\
\text { Federation by persons who have committed a crime is presumed, } \\
\text { which is absolutely unreal since not even all lawyers know } \\
\text { criminal legislation. }\end{array}$ \\
\hline
\end{tabular}

\section{Discussion}

Literally, Article 264 of the Criminal Code of the Russian Federation "Violation of road traffic regulations and rules of operation of vehicles" establishes:

A violation by a person driving a car, tram, or another mechanical vehicle of the road traffic regulations or the rules of operation of vehicles, which has caused serious harm to human health by negligence, is punishable [8].

According to the will of the legislator, the specified crime is committed only with a careless form of guilt. This is also stated in the resolution of the Plenum of the Supreme Court of the Russian Federation dd. December 9, 2008, No. 25 "On judicial practice in cases of crimes related to violations of road traffic regulations and the rules of operation of vehicles, as well as their unlawful possession without the purpose of theft" [9].

Paragraph 9 of the mentioned resolution, states: if due to a violation of road traffic regulations or the rules of operation of a vehicle, several persons were seriously injured simultaneously, the guilty person shall be criminally liable under part 1 of Article 264 of the Criminal Code of the Russian Federation.

Although these crimes are negligent, the notion that they have a much lower degree of public danger than intentional crimes is wrong.

The greatest concern of the legislator and legal experts is caused by crimes related to traffic violations by persons driving vehicles in a state of intoxication.

Some lawyers believe that road traffic regulations can be violated intentionally [10], but the harmful consequences occur through negligence. In the theory of criminal law, lawyers call this phenomenon a "mixed" form of guilt.

The authors believe that the error in Korobeev's opinion in this regard is that the violation of traffic regulations or the rules of operation of vehicles, although committed intentionally, is usually not socially dangerous since it is covered by the Code of Administrative Offences of the Russian Federation. It is harmful, and only when the dangerous consequences specified in the Criminal Code of the Russian Federation (serious harm to health or death) occur it would be criminal. Korobeev discusses the form of guilt in criminal law. In our opinion, there 
is no such form of guilt as "mixed" in the Criminal Code of the Russian Federation although the discussion about its existence in the literature is not over yet.

According to Rarog, guilt in accordance with the prevailing psychological theory of guilt in Russian science is the mental attitude of a person to a socially dangerous act committed by him/her, provided for by criminal law, and to its socially dangerous consequences.

Does the person driving the vehicle always commit such a crime by negligence?

According to its intellectual characteristics, criminal flippancy is very close to indirect intent and differs mainly in the component of will. From the frivolous hope of preventing the harmful consequences of one's act, based on real factors, one should distinguish the so-called hope for a "happy" set of circumstances i.e. luck.

Article 26 of the Criminal Code of the Russian Federation states that a person ... without sufficient grounds presumptuously counted on the prevention of these consequences. According to Dal to prevent means to pre-suspend, to avert in advance (meaning the consequences), that is, to take active actions so that these consequences do not occur [11].

Most often, the crime under Article 264 of the Criminal Code of the Russian Federation is committed by flippancy. Article 26 of the Criminal Code of the Russian Federation reveals the content of criminal flippancy: a crime is recognized as committed by flippancy if a person foresees the possibility of socially dangerous consequences of his/her actions (inaction), but without sufficient grounds for this, presumptuously counted on the prevention of these consequences.

It is impossible to conclude from the content of the text of the article concerning such an intellectual moment of flippancy as the person's awareness of the social danger of his/her act. The law speaks only about anticipating the possibility of socially dangerous consequences.

Filanovsky believes that if a person foresees the possibility of socially dangerous consequences of his/her actions, he/she is necessarily aware of the social danger of the actions themselves because the foresight of the danger of consequences is possible only if the danger of actions is understood [4]. All this corresponds to the laws of formal logic.

A strong degree of alcohol and other intoxication of the driver does not allow him/her to count on the possibility of preventing socially dangerous consequences, since the coordination of his/her actions is disrupted, the reaction is slow, he/she does not always adequately assess the situation and therefore, most likely, expects that harmful consequences will not occur or leaves it to chance, which is characteristic of a crime against the person with indirect intent.

These insufficient grounds can erase the line between flippancy and indirect intent. This was mentioned by Dagel. He noted the peculiarities of committing careless crimes in the sphere of operation of technical means or other sources of increased danger. These actions lead to the loss of control over the technical means by the person who uses them, which results in dangerous consequences [5]. Subsequently, this idea was developed by Tyazhkova [12].

Federal Law No. 146-FZ dated of June 17, 2019 "On Amendments to the Criminal Code of the Russian Federation" tightened the responsibility for committing a crime under Article 264 of the Criminal Code of the Russian Federation [13]. Part 6 of this article provides punishment for "drunk" drivers in the form of imprisonment for a term of up to fifteen years.

\section{Conclusion}

In conclusion, it can be mentioned that the problem of accurate determination of the form of guilt in the commission of such acts has not yet been completely resolved. As already said, the resolution of the Plenum of the Supreme Court of the Russian Federation No. 25 does not mention the degree of alcohol intoxication of drivers who commit such acts. According to 
the authors, these examples most likely show signs of crimes committed against the person, but not road safety.

\section{References}

1. I.N. Noss, S.V. Shport, V.G. Bulygina, Rus. J. Psy. 1, 86-91 (2018)

2. I. Petrov, Speshil na zapis treka. Zaderzhan reper, sbivshii trekh peshekhodov [He was in a hurry to record a track. Arrested rapper who hit three pedestrians]. Accessed on: March 19, 2021. [Online]. Available: https://rg.ru/2020/09/22/reg-cfo/zaderzhan-repersbivshij-treh-peshehodov-v-centre-moskvy.html. https://doi.org/10.25016/2541-74872017-0-4-83-99

3. A.I. Rarog, Problemy kvalifikatsii prestuplenii po subektivnym priznakam [Problems of qualification of crimes on subjective attributes] (Prospekt, Moscow, 2017)

4. I.G. Filanovsky, Kurs sovetskogo ugolovnogo prava [Course of Soviet criminal law], vol. 1 (Publishing House of the Leningrad University, Leningrad, 1968)

5. P.S. Dagel, Neostorozhnost: ugolovno-pravovye i kriminalogicheskie problemy [Carelessness: criminal-legal and criminological problems] (Yridicheskaya literatura, Moscow, 1977). https://doi.org/10.17308/vsu.proc.law.2020.2/2814

6. A.I. Korobeev, Ugolovno-pravovaya okhrana bezopasnosti moreplavaniya v SSSR [Criminal-legal protection of the safety of navigation in the USSR] (Izd-vo Dalnevost. un-ta, Vladivostok, 1984)

7. A.G. Ivanov, Proc. Voronezh State Univ. Ser. Law 2, 259-268 (2020). https://doi.org/10.17308/vsu.proc.law.2020.2/2814

8. Ugolovnyi kodeks Rossiiskoi Federatsii [The Criminal Code of the Russian Federation] (Prospekt, Moscow, 2018)

9. Postanovlenie Plenuma Verkhovnogo Suda RF ot 9 dekabrya 2008 g. № 25 “O sudebnoi praktike po delam o prestupleniyakh, svyazannykh s narusheniem pravil dorozhnogo dvizheniya i ekspluatatsii transportnykh sredstv, a takzhe s ikh nepravomernym zavladeniem bez tseli khishcheniya" [Resolution of the Plenum of the Supreme Court of the Russian Federation dd. December 9, 2008 No. 25 "On judicial practice in cases of crimes related to violations of road traffic regulations and the rules of operation of vehicles, as well as their unlawful possession without the purpose of theft"], Proc. of Res. Plenum Sup. Court RF on Criminal Cases, vol. 2 (Prospekt, Moscow, 2018)

10. G.N. Borzenkov et al. Ugolovnoe pravo Rossii v voprosakh i otvetakh [Criminal law of Russia in questions and answers] (Prospekt, Moscow, 2013).

11. V.I. Dal, Tolkovyi slovar zhivogo velikorusskogo yazyka [Explanatory Dictionary of the Live Great Russian Language], vol. 3 (Russkiy Yazyk, Moscow, 1980)

12. I.M. Tyazhkova, Neostorozhnye prestupleniya s ispolzovaniem istochnikov povyshennoi opasnosti [Careless crimes with the use of sources of increased danger] (Yurid. Tsentr Press, Saint Petersburg, 2002)

13. Sobranie Zakonodatelstva RF [Collection of Legislation of the Russian Federation], 25, art. 2954 (1996)

14. OECD/ITF. Road safety annual report 2019. Accessed on: March 19, 2021. [Online]. Available: http://stat.gibdd.ru

15. V.G. Bulygina, A.S. Vasilchenko, D.S. Kalinkin, S.V. Shport, Med.-bio. and Soc. Psy. Problems of Safety in Em. Sit. 4, 83-99 (2017)

16. A. Pyankova, T. Fattakhov, Demographic Rev. 6(3), 58-84 (2019). https://doi.org/10.17323/demreview.v6i3.9855

17. Rossiyskaya Gazeta No. 41 dd. 27.02.2017. Accessed on: April 13, 2021. [Online]. Available: https://rg.ru/gazeta/rg-spec/2017/02/27/1.html 